\title{
Klasifikasi Data Tidak Lengkap Dengan Pendekatan Fuzzy Grid Partition
}

\author{
Murni Marbun', Erwin Panggabean², Ricky Martin Ginting ${ }^{3}$, Robertus Rinaldy Pakpahan $^{4}$ \\ 1,2,3,4 STMIK Pelita Nusantara Medan \\ Jl. Iskandar Muda No. 1 Medan, 20154, Indonesia \\ e-mail: 1dimpleflorence@yahoo.co.id, ${ }^{2}$ erwinpanggabean8@gamil.com, \\ ${ }^{3}$ rickymartinginting503@gmail.com, ${ }^{4}$ naldipakpahan21@gmail.com
}

\begin{tabular}{llll}
\hline Informasi Artikel Diterima: 00-00-2021 & Direvisi: 00-00-2021 & Disetujui: 00-00-2021 \\
\hline
\end{tabular}

\begin{abstract}
Abstrak
Klasifikasi data tidak lengkap dapat di proses langsung dengan cara tertentu untuk mendapatkan aturannya atau diperoleh dari pengetahuan para pakar. Ketergantungan terhadap pakar akan sulit memodelkan implikasi logis manusianya, tidak tersedianya framework proses pemodelan, dan biaya pakar yang mahal. Kesulitan tersebut dapat diatasi dengan mendapatkan aturan dari data yang bersifat uncertain dengan menerapkan metode dari sistem fuzzy yang dibangun berdasarkan konsep fuzzy ifthen rules. Pendekatan metode pada penelitian ini adalah metode fuzzy grid partition untuk mengklasifikasikan data tidak lengkap. Data yang digunakan adalah data cuaca yang terdiri data kelembaban udara sebagai konklusi, data temperatur, curah hujan, lamanya penyinaran matahari dan kecepatan angin sebagai anteseden. Tahapan penelitian dimulai dengan menginput data set tidak lengkap, merubah data tidak lengkap menjadi data lengkap, menormalisasi data, membangkitkan aturan dan melakukan proses klasifikasi data. Hasil penelitian menghasilkan 22 aturan untuk mengklasifikasi data dengan tingkat akurasi $66,67 \%$, tingkat error $33,33 \%$ dan jumlah data unclass adalah 0.
\end{abstract}

Kata Kunci: klasifikasi data tidak lengkap, fuzzy if-then rules, metode fuzzy grid partition

\begin{abstract}
Classification of incomplete data can be processed directly in a certain way to get the rules or obtained from the knowledge of experts. Dependence on experts will be difficult to model the logical implications of humans, the unavailability of a modeling process framework, and expensive expert fees. This difficulty can be overcome by obtaining rules from uncertain data by applying methods from a fuzzy system that is built on the concept of fuzzy if-then rules. The method approach in this research is the fuzzy grid partition method to classify incomplete data. The data used are weather data consisting of air humidity data as a conclusion, temperature data, rainfall, duration of sunlight and wind speed as antecedents. The research phase begins with inputting incomplete data sets, changing incomplete data into complete data, normalizing data, generating rules and carrying out data classification processes. The research result are 22 rules for classifying data with an accuracy rate of $66.67 \%$, error rate of $33.33 \%$ and the number of unclass data is 0 .
\end{abstract}

Keywords: Classification of incomplete data, Fuzzy if-then rules, Fuzzy grid partition

\section{Pendahuluan}

Sebagian besar database tidak terhindar dari masalah ketidaklengkapan informasi yang berkaitan dengan nilai-nilai yang hilang atau salah. Berbagai alasan yang berbeda mengakibatkan ketidaklengkapan dalam data. Kesalahan prosedur manual entri data, pengukuran yang salah, kesalahan peralatan, dan lainnya merupakan salah satu penyebab ketidaklengkapan data (Sadiq et al., 2012) 
Dataset tidak lengkap adalah data yang nilai-nilai atribut dari beberapa objek di dataset tidak diketahui, setidaknya satu objek di dataset mempunyai missing value maka diklasifikasikan sebagai dataset tidak lengkap. Dataset tidak lengkap dapat diubah menjadi dataset lengkap dengan pendekatan mengganti nilai atribut yang hilang dengan rata-rata atau median dari atribut untuk semua objek yang memiliki kelas keputusan yang sama, seperti yang dikemukakan Han et al. (2012). Data yang telah lengkap tersebut dapat di lakukan klasifikasi untuk menemukan model atau fungsi yang menggambarkan dan membedakan kelas setiap data atau konsep data.

Model data diperoleh berdasarkan analisis dari serangkaian data pelatihan, yaitu kumpulan objek data dimana label kelas dari objek diketahui. Model ini digunakan untuk mengklasifikasi label kelas sebagai objek pada data uji. Klasifikasi merupakan penentuan sebuah record data baru ke salah satu beberapa kategori dimana telah ditentukan sebelumnya (Sinambela et al., 2016) Keakuratan klasifikasi pada data uji adalah persentase dari data uji yang telah benar diklasifikasikan oleh model, dimana label kelas masing-masing data uji yang berkaitan dibandingkan dengan hasil klasifikasi kelas dari model (Han J et al., 2014).

Penelitian ini adalah lanjutan dari penelitian sebelumnya yang membahas tentang klasifikasi sistem fuzzy berdasarkan aturan ifthen menggunakan metode grid partition (Sitompul et al, 2017).

Pada penelitian sebelumnya data yang digunakan dalam penelitian ini adalah data lengkap yang diambil dari UC Irvine machine learning repository, yang merupakan kumpulan dataset yang digunakan oleh machine learning community dalam melakukan analisis terhadap suatu algoritma machine learning. Namun, melihat dari berbagai media penyedia dataset masih ditemukan ketidaklengkapan informasi yang disebabkan kesalahan prosedur manual entri data, pengukuran yang salah, kesalahan peralatan, dan lainnya.

Model klasifikasi data tidak lengkap dapat direpresentasikan dalam bentuk aturan fuzzy (aturan If-then). Aturan fuzzy akan memetakan ruang input kedalam ruang keluaran sehingga menghasilkan keluaran fuzzy (Marbun et al., 2019). Aturan fuzzy if-then dapat dibangkitkan melalui pelatihan, antara lain: Liu et al. (2013), dengan pendekatan an axiomatic fuzzy sets decision tree. Dahal et al. (2015) dengan menggunakan algoritma genetika. Elkano et al. (2016) dengan menggunakan strategi dekomposisi biner sedangakan proses klasifikasi fuzzy menggunakan metode One Vs
One (OVO) dan One Vs All (OVA) untuk dekomposisi binernya.

Pendekatan metode fuzzy grid-partition dapat digunakan dalam perancangan sistem fuzzy karena lebih mudah digunakan (Hartono, 2016). Beberapa penelitian untuk mengklasifikasi pola dengan pendekatan fuzzy grid partition antara lain: Chen et al. (2014) membangkitkan beberapa rules dengan menggunakan grid partition sederhana, kemudian melakukan perubahan bobot rules dengan algoritma particle swarm optimization dan Takahashi et al. (2015) melakukan seleksi rules yang dibangkitkan dengan grid-parition terdistribusi menggunakan dua fungsi objektif yang saling berotasi. Selain mengklasifikasikan pola, metode grid partition juga digunakan untuk mengkombinasi pendekatan tekstur, grey-level co-occurrence matrices dengan sistem inferensi fuzzy berbasis grid partition, bernama ANFISGRID untuk klasifikasi radar yang bergema (Sadouki \& Haddad, 2016), untuk memilih fitur berdasarkan Grid Partition Data Field (FSGPDF) (Field \& Zhao, 2018), dan Mao et al. (2020) menerapakan algoritma Quantuminspired Quantum-behaved Particle Swarm Optimization (QiQPSO) untuk membangun klasifikasi awal sistem fuzzy dan metode grid untuk mempartisi ruang fitur, dan kemudian basis aturan fuzzy dioptimalkan lebih lanjut oleh QiQPSO untuk mengurangi jumlah aturan fuzzy sehingga meningkatkan interpretabilitas akurasi klasifikasi yang lebih tinggi.

Sitompul et al. (2017) menggunakan pendekatan adaptive distributed grid-partition. Dengan metode ini, jumlah aturan yang dihasilkan dapat disesuaikan dengan kebutuhan sehingga akurasi sistem serta kompleksitas waktu inferensi dapat dikelola dengan baik. Pendekatan grid-partition teradaptasi dapat membangkitkan fuzzy rules dengan jumlah yang lebih sedikit bila dibandingkan dengan pendekatan grid-partition terdistribusi dengan kriteria berhenti yang sama, yaitu ketika akurasi rules yang dibangkitkan terhadap rekam data learning telah mencapai $100 \%$.

Tujuan dari penelitian ini adalah mengklasifikasikan data tidak lengkap dengan pendekatan metode fuzzy grid partition. Klasifikasi data dengan metode fuzzy grid partition dimensi $\mathrm{n}$ dengan $\mathrm{m}$ label adalah $\mathrm{X}^{\mathrm{p}}=$ $\left(X_{1}^{p}, X_{2}^{p} \ldots X_{n}^{p}\right), \mathrm{p}=1,2 \ldots \mathrm{m}$, merupakan himpunan pelatihan yang dilambangkan sebagai data pelatihan dan kelas $C$ sebagai $y_{1}, y_{2} \ldots y c$. $X_{j}^{p}$ adalah contoh nilai ke-i dari atribut $\mathrm{p}$. Maka pembangkitan aturan fuzzy if-then dari data numerik mencakup dua fase yaitu (Borgi, 2018): 1. Fase Pertama

Pada fase pertama, untuk membangkitkan aturan fuzzy menggunakan pendekatan grid 
partition, ruang pencarian dibagi menjadi beberapa partisi untuk membentuk struktur grid. Setiap atribut numerik dipartisi menjadi subset $K$ fuzzy $\left\{A_{1}, A_{2}, \ldots, A_{K}\right\}$, di mana setiap subset ditentukan oleh fungsi keanggotaan sehingga diperoleh fuzzy grid.

2. Fase kedua

Pada fase kedua, aturan fuzzy if-then dibangun untuk setiap subruang dari fuzzy grid. Grid yang terbentuk oleh kombinasi relasi dari setiap partisi akan menghasilkan aturan. Gambar 1 merupakan contoh grid fuzzy sederhana di mana semua atribut dipartisi dengan jumlah yang sama yaitu $\mathrm{K}=$ 5 dari subset fuzzy. Dengan demikian jumlah aturan fuzzy yang dihasilkan adalah $5^{2}$. Secara umum, jika masalah dimensi-n dengan subset $K$ fuzzy untuk partisi fuzzy, maka aturan fuzzy yang diperoleh sebanyak $\mathrm{K}^{\mathrm{n}}$.

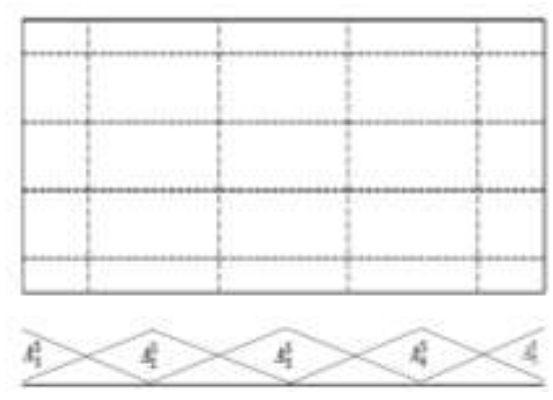

Sumber: Borgi (2018)

\section{Gambar 1. Partisi Fuzzy Grid}

Untuk membangkitkan aturan fuzzy if-then yang dibagi menjadi beberapa area ruang pola keputusan maka, aturan fuzzy if-then sebagai berikut (Sitompul et al. 2017):

$R_{i j}^{K}:$ IF $x_{i}$ is $A_{i}^{K}$ AND $x_{j}$ is $A_{j}^{K}$ THENC;CF $F_{i j}^{K}$

dimana:

$R_{i j}^{K}$ adalah label aturan

$A_{i}^{K}$ dan $A_{j}^{K}$ adalah premis

$\mathrm{K}$ adalah jumlah partisi

$C$ adalah konklusi

CF adalah bobot aturan

i dan $\mathrm{j}$ adalah $1,2, \ldots, \mathrm{K}$

\section{Metode Penelitian}

Metode penelitian adalah kerangka kerja untuk melakukan suatu tindakan, atau suatu kerangka berpikir untuk menyusun gagasan yang terarah dan terkait dengan maksud dan tujuan. Untuk menyelesaikan penelitian ini maka perlu adanya susunan kerangka kerja (frame work) yang jelas tahapan-tahapannya seperti pada gambar 2. Adapun tahapan penelitian sebagai berikut:

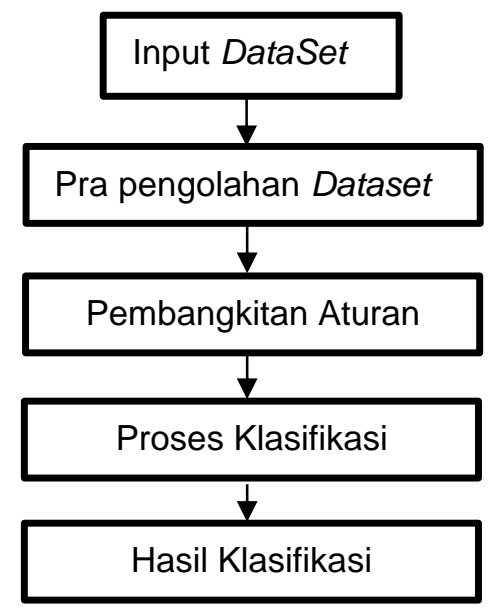

Gambar 2. Tahapan Penelitian

Tahapan penelitian sebagai berikut:

1. Input DataSet

Dataset yang di input pada penelitian ini adalah dataset yang bersumber dari data sekunder yang dikumpulkan dari Stasiun Meteorologi Maritim Belawan melalui link: https://dataonline.bmkg.go.id/data_iklim.

Periode pengumpulan data dimulai dari data cuaca bulan Januari tahun $2021 \mathrm{~s} / \mathrm{d}$ bulan April 2021. Data set yang tersedia sebanyak 120 rekam data, dengan 4 atribut yaitu Temperatur, Curah Hujan, Lamanya Penyinaran Matahari, Kecepatan Angin dan Kelembaban Udara.

2. Pra Pengolahan Data

a. Dataset tidak lengkap dapat diubah menjadi dataset lengkap dengan pendekatan mengganti nilai atribut yang hilang dengan rata-rata atau median dari atribut untuk semua objek yang memiliki kelas keputusan yang sama, seperti yang dikemukakan Han et al. (2012).

b. Kategorisasi Data

Sebelum menormalisasi data, dataset yang berupa nilai numerik diubah ke dalam bentuk nilai kategorikal. Berikut kategorisasi untuk setiap atribut

1. Kelembaban Udara (KU)

$$
K U=\left\{\begin{array}{lr}
\text { Kering, } & K U \leq 74 \\
\text { Lembab, } & <4 \quad K U<80 \\
\text { Basah, } & K U \geq 80
\end{array}\right.
$$

2. Temperatur $(\mathrm{T})$

$$
T=\left\{\begin{array}{cc}
\text { Dingin, } & T \leq 26,5 \\
\text { Normal, } 26,5<T<29 \\
\text { Panas, } & T \geq 29
\end{array}\right.
$$

3. Curah Hujan $(\mathrm{CH})$

$$
G H= \begin{cases}\text { Ringan, } & C H \leq 20 \\ \text { Normal, } 20 & <\mathrm{CH}<50 \\ \text { Lebat, } & C H \geq 50\end{cases}
$$

4. Lamanya Penyinaran Matahari (LPM) 


$$
L P M=\left\{\begin{array}{cc}
\text { Rendah, } & L P M \leq 2.16 \\
\text { Normal, } 2.16 & <L P M<8.28 \\
\text { Tinggi, } & L P M \geq 8.28
\end{array}\right.
$$

5. Kecepatan Angin (KA)

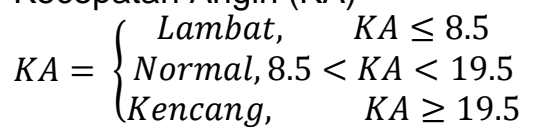

c. Normalisasi Data

Normalisasi nilai atribut dataset dilakukan dengan cara mengubah interval nilai atribut dataset yang sebenarnya ke dalam interval tertentu, dalam kasus ini diubah ke dalam interval $[0,1]$.

$$
X_{\text {baru }}=\frac{x-x \min }{x \max -x \min }
$$

3. Pembangkitan aturan dengan pendekatan metode fuzzy grid partition

a. Menentukan titik pusat dan lebar fungsi keanggotaan untuk mendapatkan aturan yang dibangkitkan.

$$
\begin{aligned}
a_{i}^{K} & =\frac{i-1}{K-1}, i=1,2,3, \ldots, K \\
b^{K} & =\frac{1}{(K-1)}
\end{aligned}
$$

dimana, $\mathrm{K}$ adalah jumlah partisi. $a_{K}^{i}$ adalah titik pusat untuk masing-masing fungsi segitiga dan $b^{K}$ adalah jarak dari titik pusat ke kaki fungsi segitiga

b. Penghitungan $\mu$ pada $\mathrm{K}$ pada masing masing atribut.

$$
\begin{aligned}
& \mu_{i}^{K}(x)=\max \left\{1-\left|x-a_{i}^{K}\right| / b^{K}, 0\right\} \\
& \operatorname{dimana}: \\
& \quad \mathrm{i}=1,2, \ldots, \mathrm{K}
\end{aligned}
$$

c. Menghitung a-predikat pada masingmasing kelas terhadap semua aturan yang berpotensi untuk dibangkitkan

$$
\beta_{C t}=\sum_{p \epsilon C t} \mu_{i}^{K}\left(x_{p 1}\right) \cdot\left(\mu_{j}^{K}\left(x_{p 2}\right)\right.
$$

d. menentukan nilai $\alpha$-predikat yang terbesar pada masing-masing calon aturan yang sama. Nilai $\alpha$-predikat yang terbesar dinamakan $\beta$.

$\beta_{C x}=\max \left\{\beta_{C 1}, \beta_{C 2}, \ldots, \beta_{C M}\right\}$

e. Penentuan $\beta$ dengan membandingkan semua $\alpha$-predikat pada calon aturan yang sama disetiap kelas.

f. Penentuan konklusi dari aturan berdasarkan nilai $\beta$ yang terbesar

g. yang selanjutnya dinamakan $\beta$ max. Bila terdapat dua atau lebih $\beta \max$ yang memiliki nilai yang sama, atau nilai $\beta$ max bernilai 0 , maka konklusi tidak dapat ditentukan, rules tidak dapat dibangkitkan

h. Penghitungan bobot aturan (CF) untuk mendapatkan aturan.

$$
C F_{i j}^{K}=\frac{\left|\beta_{C x}-\beta\right|}{\sum_{t=1}^{M} \beta_{C t}},
$$

dimana:

$$
\beta=\sum_{C t \neq C X} \beta_{C t} /(M-1)
$$

i. Menerapkan teknik representase adaptif grid partition untuk pembentukan struktur gridnya berdasarkan bobot $C F$. Pembangkitan aturan dilakukan dengan 2 fase. Fase pertama akan dibentuk grid sehalus mungkin dengan ketentuan semua kemungkinan aturan dapat dibangkitkan, atau iterasi akan berhenti ketika ada aturan yang memiliki bobot bernilai satu. Sedangkan fase kedua akan dibangkitkan aturan baru dengan bobot yang lebih tinggi untuk meningkatkan akurasi dari aturan tersebut.

4. Proses Klasifikasi

Proses klasifikasi dilakukan untuk mengetahui keakuratan aturan yang telah dibangkitkan dengan cara:

a. Hitung nilai a masing-masing kelas, dimana a merupakan hasil perkalian antara $\alpha$-predikat dengan bobot aturan.

$$
\begin{aligned}
& \alpha_{C t}=\max \left\{\left(\mu _ { i } ^ { K } ( x _ { p 1 } ) \cdot \left(\mu_{j}^{K}\left(x_{p 2}\right) .\right.\right.\right. \\
& \left.C F_{i j}^{K} \mid C_{i j}^{K}=C t ; R_{i j}^{K} \in S_{R}\right\}
\end{aligned}
$$

b. Tentukan nilai a yang terbesar pada masing-masing kelas.

$$
\alpha_{C X}=\max \left\{\alpha_{C 1}, \alpha_{C 2}, \ldots, \alpha_{C M}\right\}
$$

c. kemudian tentukan nilai $\alpha_{\max }$ dari masingmasing kelas.

d. Hitung tingkat keakuratan aturan, error aturan dan jumlah unclass dari aturan yang dibangkitkan.

$$
\begin{aligned}
& \text { akurasi (\%) } \\
& =\frac{\sum \text { klasifikasi yang benar }}{\sum \text { klasifikasi keseluruhan }} \times 100 \% \\
& \text { error }(\%) \\
& \quad=\frac{\sum \text { klasifikasi yang salah }}{\sum \text { klasifikasi keseluruhan }} \times 100 \%
\end{aligned}
$$

\section{乏unclass}

$=\Sigma$ klasifikasi keseluruhan $-(\Sigma$ klasifikasi benar $+\Sigma$ klasifikasi salah)

5. Hasil Klasifikasi

Hasil klasifikasi diperoleh pada saat proses learning akan berhenti setelah batas minimal keakuratan yang diinginkan terhadap data learning telah dipenuhi.

\section{Hasil dan Pembahasan}

Pembangkitan aturan fuzzy menggunakan sampel data sebanyak 6 data yang terdapat pada 2 data di kelas kering, 2 data di kelas lembab dan 2 data di kelas basah. Sampel data seperti pada tabel 2 berikut.

Tabel 2. Enam Sampel Dataset 


\begin{tabular}{cccccc}
\hline \multirow{2}{*}{$\begin{array}{c}\text { No. } \\
\text { Rekam } \\
\text { Data }\end{array}$} & \multicolumn{4}{c}{ Atribut } & \multirow{2}{*}{ Kelas } \\
\cline { 2 - 5 } & CH & LPM & KA & \\
\hline 55 & 0.67 & 0.00 & 0.70 & 0.50 & Kering \\
91 & 1.00 & 0.00 & 0.34 & 1.00 & Kering \\
37 & 0.64 & 0.01 & 0.41 & 1.00 & Lembab \\
46 & 0.73 & 0.00 & 0.83 & 1.00 & Lembab \\
86 & 0.58 & 0.03 & 0.66 & 0.50 & Basah \\
98 & 0.60 & 0.20 & 0.03 & 1.00 & Basah \\
\hline
\end{tabular}

\subsection{Pembangkitan Aturan}

Pembangkitan aturan dengan pendekatan metode fuzzy grid partition sebagai berikut:

a. Perhitungan titik pusat dan lebar fungsi

Dengan mengikutsertakan semua variabel linguistik pada $K=2$, sebagai contoh:

$a_{1}^{2}$ dan $b^{2}$ dihitung sebagai berikut:

$a_{1}^{2}=(1-1) /(2-1)=0 / 1=0$

$b^{2}=1 /(2-1)=1 / 1=1$

dengan cara yang sama, akan diperoleh $a_{2}^{2}$ dan $b^{2}$

$a_{2}^{2}=(2-1) /(2-1)=1 / 1=1$

$b^{2}=1 /(2-1)=1 / 1=1$

Maka terdapat 16 aturan yang berpotensi untuk dibangkitkan, yang diperoleh dari Kd, dimana d adalah jumlah atribut dataset. Calon aturan tersebut pada $\mathrm{K}=2$ adalah sebagai berikut:

1. $\quad R_{1111}^{2}$ :IF T is $A_{1}^{2}$ AND CH is $A_{1}^{2}$ AND LPM is $A_{1}^{2}$ And $K A$ is $A_{1}^{2}$ THEN $K U$ is $C$

2. $R_{1112}^{2}$ :IF T is $A_{1}^{2}$ AND CH is $A_{1}^{2}$ AND LPM is $A_{1}^{2}$ AND KA is $A_{2}^{2}$ THEN KU is $C$

3. $R_{1121}^{2}$ IF T is $A_{1}^{2}$ AND CH is $A_{1}^{2}$ AND LPM is $A_{2}^{2}$ AND KA is $A_{1}^{2}$ THEN $K U$ is $C$

4. $R_{1122}^{2}$ IF T is $A_{1}^{2}$ AND CH is $A_{1}^{2}$ AND LPM is $A_{2}^{2}$ AND KA is $A_{2}^{2}$ THEN KU is $C$

5. $R_{1211}^{2}$ :IF T is $A_{1}^{2}$ AND CH is $A_{2}^{2}$ AND LPM is $A_{1}^{2}$ AND KA is $A_{1}^{2}$ THEN KU is $C$

6. $R_{1212}^{2}$ IF T is $A_{1}^{2}$ AND CH is $A_{2}^{2}$ AND LPM is $A_{1}^{2}$ AND KA is $A_{2}^{2}$ THEN KU is $C$

7. $R_{1221}^{2}$ :IF T is $A_{1}^{2}$ AND CH is $A_{2}^{2}$ AND LPM is $A_{2}^{2}$ AND KA is $A_{1}^{2}$ THEN KU is $C$

8. $\quad R_{1222}^{2}$ IF T is $A_{1}^{2}$ AND CH is $A_{2}^{2}$ AND LPM is $A_{2}^{2}$ AND KA is $A_{2}^{2}$ THEN $K U$ is $C$

9. $R_{2111}^{2}$ :IF T is $A_{2}^{2}$ AND CH is $A_{1}^{2}$ AND LPM is $A_{1}^{2}$ AND KA is $A_{1}^{2}$ THEN KU is $C$

10. $R_{2112}^{2}$ :IF T is $A_{2}^{2}$ AND CH is $A_{1}^{2}$ AND LPM is $A_{1}^{2}$ AND KA is $A_{2}^{2}$ THEN KU is $C$

11. $R_{2121}^{2}$ :IF T is $A_{2}^{2}$ AND CH is $A_{1}^{2}$ AND LPM is $A_{2}^{2}$ AND KA is $A_{1}^{2}$ THEN KU is $C$

12. $R_{2122}^{2}$ :IF T is $A_{2}^{2}$ AND CH is $A_{1}^{2}$ AND LPM is $A_{2}^{2}$ AND KA is $A_{2}^{2}$ THEN KU is $C$

13. $R_{2211}^{2}$ :IF T is $A_{2}^{2}$ AND CH is $A_{2}^{2}$ AND LPM is $A_{1}^{2}$ AND KA is $A_{1}^{2}$ THEN $K U$ is $C$

14. $R_{2212}^{2}$ :IF T is $A_{2}^{2}$ AND CH is $A_{2}^{2}$ AND LPM is $A_{1}^{2}$
AND KA is $A_{2}^{2}$ THEN KU is $C$

15. $R_{2221}^{2}$ :IF T is $A_{2}^{2}$ AND CH is $A_{2}^{2}$ AND LPM is $A_{2}^{2}$ AND KA is $A_{1}^{2}$ THEN $K U$ is $C$

16. $R_{2222}^{2}$ :IF T is $A_{2}^{2}$ AND CH is $A_{2}^{2}$ AND LPM is $A_{2}^{2}$ AND KA is $A_{2}^{2}$ THEN KU is $C$

b. Derajat Keanggotaan pada $\mathrm{K}=2$

Perhitungan $\mu$ data temperatur ke 55 pada $\mathrm{K}$ $=2$ sebagai berikut:

$\mu_{1}^{2}(0.67)=\frac{1.00-0.67}{1.00-0.00}=0.33$

Perhitungan $\mu$ untuk semua rekam data dapat dilihat pada tabel 3.

Tabel 3. Derajat keanggotaan pada $\mathrm{K}=2$

\begin{tabular}{cccccc}
\hline Class (No. & Label & \multicolumn{4}{c}{ Derajat Keanggotaan } \\
\cline { 3 - 6 } rekam data) & $\mu$ & $\mathrm{T}$ & $\mathrm{CH}$ & $\mathrm{LPM}$ & $\mathrm{KA}$ \\
\hline \multirow{2}{*}{ Kering (55) } & $\mu_{1}^{2}$ & 0.33 & 1 & 0.3 & 0.5 \\
& $\mu_{2}^{2}$ & 0.67 & 0 & 0.7 & 0.5 \\
Kering (91) & $\mu_{1}^{2}$ & 0 & 1 & 0.66 & 0 \\
& $\mu_{2}^{2}$ & 1 & 0 & 0.34 & 1 \\
Lembab (37) & $\mu_{1}^{2}$ & 0.36 & 0.99 & 0.59 & 0 \\
& $\mu_{2}^{2}$ & 0.64 & 0.01 & 0.41 & 1 \\
Lembab (46) & $\mu_{1}^{2}$ & 0.27 & 1 & 0.17 & 0 \\
& $\mu_{2}^{2}$ & 0.73 & 0 & 0.83 & 1 \\
Basah (86) & $\mu_{1}^{2}$ & 0.42 & 0.97 & 0.34 & 0.5 \\
& $\mu_{2}^{2}$ & 0.58 & 0.03 & 0.66 & 0.5 \\
Basah (98) & $\mu_{1}^{2}$ & 0.4 & 0.8 & 0.97 & 0 \\
& $\mu_{2}^{2}$ & 0.6 & 0.2 & 0.03 & 1 \\
\hline
\end{tabular}

c. Nilai $\alpha$-predikat

Perhitungan $\alpha$-predikat dilakukan pada dataset dengan rekam data nomor 55 pada label aturan $R_{1112}^{2}$ dengan persamaan:

$R_{1112}^{2}=\mu_{1}^{2}(\mathrm{~T}) \cdot \mu_{1}^{2}(\mathrm{CH}) \cdot \mu_{1}^{2}(\mathrm{LPM}) \cdot \mu_{2}^{2}(\mathrm{KA})$

$R_{1112}^{2}=(0.33)(1)(0.3)(0.5)$

$R_{1112}^{2}=0.0495$

dengan cara yang sama, semua $\alpha$-predikat dihitung untuk kelas kering, lembab dan basah dapat dilihat pada tabel 4 , tabel 5 dan tabel 6 .

Tabel 4. $\alpha$-predikat Kelas Kering

\begin{tabular}{|c|c|c|c|c|c|c|}
\hline$R_{i j k_{1}}^{K}$ & $\begin{array}{l}\text { No. } \\
\text { Data }\end{array}$ & $\begin{array}{l}\text { T } \\
\text { is } A_{i}^{K}\end{array}$ & $\begin{array}{l}\mathrm{CH} \\
\text { is } A_{j}^{K}\end{array}$ & $\begin{array}{l}\text { LPM } \\
\text { is } A_{K}^{K}\end{array}$ & $\begin{array}{l}\text { KA } \\
\text { is } A_{l}^{K}\end{array}$ & $\alpha$ \\
\hline & 55 & 0.33 & 1 & $0.3^{n}$ & 0.5 & 0.0495 \\
\hline$R_{111}^{2}$ & 91 & 0 & 1 & 0.66 & 0 & \\
\hline & 55 & 0.33 & 1 & 0.3 & 0.5 & 0.0495 \\
\hline$R_{111}^{1}$ & 91 & 0 & 1 & 0.66 & 1 & 0 \\
\hline - & . & . & . & . & . & . \\
\hline . & . & . & . & · & . & . \\
\hline$D^{2}$ & 55 & 0.67 & 0 & 0.7 & 0.5 & 0 \\
\hline$R_{222}^{2}$ & 91 & 1 & 0 & 0.34 & 1 & 0 \\
\hline
\end{tabular}


Tabel 5. $\alpha$-predikat Kelas Lembab

Tabel 8. Nilai $\beta$ Kelas Lembab

\begin{tabular}{|c|c|c|c|c|c|c|c|c|c|c|}
\hline$R_{i j k l}^{K}$ & $\begin{array}{l}\text { No. } \\
\text { Data }\end{array}$ & $\begin{array}{l}\mathrm{T} \text { is } \\
A_{i}^{K}\end{array}$ & $\begin{array}{l}\mathrm{CH} \\
\text { is } A_{j}^{K} \\
\end{array}$ & $\begin{array}{l}\text { LPM } \\
\text { is } A_{k}^{K}\end{array}$ & $\begin{array}{l}\mathrm{KA} \\
\text { is } A_{l}^{K} \\
\end{array}$ & $\alpha$ & \multirow{2}{*}{$R_{i j k l}^{K}$} & \multirow{2}{*}{\multicolumn{2}{|c|}{$\begin{array}{c}\alpha-\text { predikat Pada } \\
\text { Rekam Data }\end{array}$}} & \multirow[t]{2}{*}{$\beta$} \\
\hline$R_{1111}^{2}$ & $\begin{array}{l}37 \\
46\end{array}$ & $\begin{array}{l}0.36 \\
0.73\end{array}$ & $\begin{array}{l}0.99 \\
0\end{array}$ & $\begin{array}{l}0.59 \\
0.83\end{array}$ & $\begin{array}{l}0 \\
1\end{array}$ & $\begin{array}{l}0 \\
0\end{array}$ & & & & \\
\hline$R_{1112}^{2}$ & 37 & 0.36 & 0.99 & 0.59 & 1 & 0.2103 & $R_{1111}^{2}$ & $\begin{array}{c}0 \\
0\end{array}$ & 0 & 0 \\
\hline 41112 & 46 & 0.27 & 1 & 0.17 & 1 & 0.0459 & $R_{1112}^{2}$ & 0.21028 & 0.0459 & 0.21028 \\
\hline$\cdot$ & $\cdot$ & - & - & - & - & - & $\cdot$ & . & - & . \\
\hline : & $\cdot$ & $\cdot$ & - & - & - & - & - & - & - & - \\
\hline$R_{2222}^{2}$ & $\begin{array}{l}37 \\
46 \\
\end{array}$ & $\begin{array}{l}0.64 \\
0.73 \\
\end{array}$ & $\begin{array}{l}0.01 \\
0\end{array}$ & $\begin{array}{l}0.41 \\
0.83 \\
\end{array}$ & $\begin{array}{l}1 \\
1\end{array}$ & $\begin{array}{l}0.0026 \\
0\end{array}$ & $R_{2222}^{2^{*}}$ & 0.00262 & 0 & 0.00262 \\
\hline
\end{tabular}

Tabel 6. $\alpha$-predikat Kelas Basah

\begin{tabular}{lclllll}
\hline$R_{i j k l}^{K}$ & $\begin{array}{c}\text { No. } \\
\text { Data }\end{array}$ & $\begin{array}{l}\mathrm{T} \text { is } \\
A_{i}^{K}\end{array}$ & $\begin{array}{l}\mathrm{CH} \\
\text { is } A_{j}^{K}\end{array}$ & $\begin{array}{l}\text { LPM } \\
\text { is } A_{k}^{K}\end{array}$ & $\begin{array}{l}\mathrm{KA} \\
\text { is } A_{l}^{K}\end{array}$ & $\alpha$ \\
\hline$R_{1111}^{2}$ & 86 & 0.42 & 0.97 & 0.34 & 0.5 & 0.069 \\
& 98 & 0.4 & 0.8 & 0.97 & 0 & 0 \\
$R_{1112}^{2}$ & 86 & 0.42 & 0.97 & 0.34 & 0.5 & 0.069 \\
. & 98 & 0.4 & 0.8 & 0.97 & 1 & 0.310 \\
$\cdot$ &. &. &. &. &. &. \\
$\cdot$ &. &. &. &. &. &. \\
$\cdot$ &. &. &. &. &. &. \\
$R_{2222}^{2}$ & 86 & 0.58 & 0.03 & 0.66 & 0.5 & 0.006 \\
\end{tabular}

d. Penentuan $\beta$

Perhitungan nilai $\beta$ dilakukan dengan membandingkan semua $\alpha$-predikat pada calon aturan yang sama. Sebagai simulasi, calon aturan $R_{1112}^{2}$ pada kelas kering, dilakukan dengan membandingkan nilai $\alpha$-predikat pada dataset dengan rekam data nomor 55 dan rekam data nomor 91 , seperti pada persamaan berikut: $\beta=\max \{0.0495 ; 0\}=0.0495$ $\beta=0.0495$ dengan cara yang sama, nilai $\beta$ pada masingmasing kelas kering, kelas lembab dan kelas basah dapat dilihat pada tabel 7 , tabel 8 dan tabel 9.

Tabel 7. Nilai $\beta$ Kelas Kering

\begin{tabular}{cccc}
\hline \multirow{2}{*}{$R_{i j k l}^{K}$} & \multicolumn{2}{c}{$\alpha-$ predikat } & \multirow{2}{*}{$\beta$} \\
\cline { 2 - 3 } & Pada Rekam Data & \\
\hline$R_{1111}^{2}$ & 0.0495 & 91 & \\
$R_{1112}^{2}$ & 0.0495 & 0 & 0.0495 \\
$\cdot$ & $\cdot$ & $\cdot$ & 0.0495 \\
$\cdot$ & $\cdot$ & $\cdot$ & $\cdot$ \\
$R_{2222}^{2}$ & 0 & 0 & $\cdot$ \\
\hline
\end{tabular}

Tabel 9. Nilai $\beta$ Kelas Basah

\begin{tabular}{cccc}
\hline & \multicolumn{2}{c}{$\alpha-$ predikat } & \multirow{2}{*}{$\beta$} \\
\cline { 2 - 3 }$R_{i j k l}^{K}$ Pada Rekam Data & \\
\cline { 2 - 3 } & 86 & 98 & \\
\hline$R_{1111}^{2}$ & 0.06926 & 0 & 0.06926 \\
$R_{1112}^{2}$ & 0.06926 & 0.3104 & 0.3104 \\
$\cdot$ & $\cdot$ & $\cdot$ & $\cdot$ \\
$\cdot$ & $\cdot$ & $\cdot$ & $\cdot$ \\
$R_{2222}^{2}$ & 0.00574 & 0.0036 & 0.00574 \\
\hline
\end{tabular}

e. Penentuan Konklusi

Konklusi-konklusi dari aturan ditentukan berdasarkan nilai $\beta$ yang terbesar diantara $\beta$ kering, $\beta$ lembab, dan $\beta$ basah, yang selanjutnya dinamakan $\beta$ max. Bila terdapat dua atau lebih $\beta$ max yang memiliki nilai yang sama, atau nilai $\beta \max$ bernilai 0 , maka konklusi tidak dapat ditentukan, aturan tidak dapat dibangkitkan. Nilai $\beta$ max untuk $R_{1111}^{2}$ ditentukan sebagai berikut:

$\beta \max =\max \{\beta$ kering, $\beta$ lembab, dan $\beta$ basah $\}$ $=\max \{0.0495,0,0.06926\}$ $=0.06926$

Rekapitulasi hasil perhitungan nilai $\beta$ max dapat dilihat pada tabel 10.

Tabel 10. Rekapitulasi $\beta \max$

\begin{tabular}{cccccl}
\hline \multirow{2}{*}{$R_{i j k l}^{K}$} & \multicolumn{2}{c}{$\left.\sum \mu_{i}^{K}(\mathrm{~T}) \cdot \mu_{j}^{K}(\mathrm{CH}) \cdot \mu_{k}^{K}(\mathrm{LPM}) \cdot \mu_{l}^{K}(\mathrm{KA})\right\}$} & & & \\
\cline { 2 - 5 } & $\beta$ kering & $\beta$ lembab & $\beta$ basah & Konklusi \\
\hline$R_{1111}^{2}$ & 0.0495 & 0 & 0.06926 & 0.06926 & Basah \\
$R_{1112}^{2}$ & 0.0495 & 0.21028 & 0.3104 & 0.3104 & Basah \\
$R_{1121}^{2}$ & 0.1155 & 0 & 0.13444 & 0.13444 & Basah \\
$R_{1122}^{2}$ & 0.1155 & 0.2241 & 0.13444 & 0.2241 & Lembab \\
$R_{1211}^{2}$ & 0 & 0 & 0.00214 & 0.00214 & Basah \\
$R_{1212}^{2}$ & 0 & 0.00212 & 0.0776 & 0.0776 & Basah \\
$R_{1221}^{2}$ & 0 & 0 & 0.00416 & 0.00416 & Basah \\
$R_{1222}^{2}$ & 0 & 0.00148 & 0.00416 & 0.00416 & Basah \\
$R_{2111}^{2}$ & 0.1005 & 0 & 0.09564 & 0.1005 & Kering \\
$R_{2112}^{2}$ & 0.66 & 0.37382 & 0.4656 & 0.66 & Kering \\
$R_{2121}^{2}$ & 0.2345 & 0 & 0.18566 & 0.2345 & Kering \\
$R_{2122}^{2}$ & 0.34 & 0.6059 & 0.18566 & 0.6059 & Lembab \\
$R_{2211}^{2}$ & 0 & 0 & 0.00296 & 0.00296 & Basah \\
$R_{2212}^{2}$ & 0 & 0.00378 & 0.1164 & 0.1164 & Basah \\
$R_{2221}^{2}$ & 0 & 0 & 0.00574 & 0.00574 & Basah \\
$R_{2222}^{2}$ & 0 & 0.00262 & 0.00574 & 0.00574 & Basah \\
\hline
\end{tabular}


f. Perhitungan Bobot Aturan

Sebagai simulasi, perhitungan bobot aturan pada $R_{1111}^{2}$ dilakukan sebagai berikut:

$C F_{1111}^{2}=\frac{|0.069258-(0.0495+0) / 2|}{0.069258+0.0495+0}$

$C F_{1111}^{2}=\frac{0.0445}{0.1188}$

$C F_{1111}^{2}=0.3748$

Rekapitulasi untuk perhitungan bobot aturan $C F_{i j k l}^{K}$ pada $\mathrm{K}=2$ dapat dilihat pada table 11 .

Tabel 11. Bobot Aturan

\begin{tabular}{clcc}
\hline No. & $R_{i j k l}^{K}$ & Konklusi & $C F_{i j k l}^{K}$ \\
\hline 1 & $R_{1111}^{2}$ & Basah & 0.374779 \\
2 & $R_{1112}^{2}$ & Basah & 0.31659 \\
3 & $R_{1121}^{2}$ & Basah & 0.306839 \\
4 & $R_{1122}^{2}$ & Lembab & 0.209114 \\
5 & $R_{1211}^{2}$ & Basah & 1 \\
6 & $R_{1212}^{2}$ & Basah & 0.960037 \\
7 & $R_{1221}^{2}$ & Basah & 1 \\
8 & $R_{1222}^{2}$ & Basah & 0.607029 \\
9 & $R_{2111}^{2}$ & Kering & 0.512384 \\
10 & $R_{2112}^{2}$ & Kering & 0.315513 \\
11 & $R_{2121}^{2}$ & Kering & 0.558123 \\
12 & $R_{2122}^{2}$ & Lembab & 0.303185 \\
13 & $R_{2211}^{2}$ & Basah & 1 \\
14 & $R_{2212}^{2}$ & Basah & 0.952869 \\
15 & $R_{2221}^{2}$ & Basah & 1 \\
16 & $R_{2222}^{2}$ & Basah & 0.529524 \\
\hline
\end{tabular}

Dengan cara yang sama seperti pada $K=2$, rekapitulasi pembangkitan aturan fuzzy pada $\mathrm{K}=$ 3 dapat dilihat pada tabel 12, dan rekapitulasi aturan fuzzy yang hanya dapat dibangkitkan pada $\mathrm{K}=4$ dapat dilihat pada tabel 13 .

Tabel 12. Pembangkitan Aturan Fuzzy K = 3

\begin{tabular}{cccc}
\hline No. & $R_{i j k l}^{K}$ & Konklusi & $C F_{i j k l}^{K}$ \\
\hline 1 & $R_{2113}^{3}$ & Basah & 0.670513 \\
2 & $R_{2122}^{3}$ & Basah & 0.363295 \\
3 & $R_{2123}^{3}$ & Lembab & 0.928876 \\
4 & $R_{2132}^{3}$ & Kering & 0.255481 \\
5 & $R_{2133}^{3}$ & Lembab & 1 \\
6 & $R_{2213}^{3}$ & Basah & 0.987185 \\
7 & $R_{2222}^{3}$ & Basah & 1 \\
8 & $R_{2223}^{3}$ & Basah & 0.428793 \\
9 & $R_{2232}^{3}$ & Basah & 1 \\
10 & $R_{2322}^{3}$ & Basah & 1 \\
11 & $R_{2332}^{3}$ & Basah & 1 \\
12 & $R_{3113}^{3}$ & Kering & 0.495454 \\
13 & $R_{3122}^{3}$ & Kering & 0.499112 \\
\hline
\end{tabular}

\begin{tabular}{cccc}
\hline No. & $R_{i j k l}^{K}$ & Konklusi & $C F_{i j k l}^{K}$ \\
\hline 14 & $R_{3123}^{3}$ & Kering & 0.618166 \\
15 & $R_{3132}^{3}$ & Kering & 0.607925 \\
16 & $R_{3133}^{3}$ & Lembab & 1 \\
17 & $R_{3213}^{3}$ & Basah & 0.98016 \\
18 & $R_{3222}^{3}$ & Basah & 1 \\
19 & $R_{3223}^{3}$ & Basah & 0.26661 \\
20 & $R_{3232}^{3}$ & Basah & 1 \\
21 & $R_{3322}^{3}$ & Basah & 1 \\
22 & $R_{3332}^{3}$ & Basah & 1 \\
\hline
\end{tabular}

Tabel 13. Pembangkitan Aturan Fuzzy K = 4

\begin{tabular}{|c|c|c|c|}
\hline No. & $R_{i j k l}^{K}$ & Konklusi & $C F_{i j k l}^{K}$ \\
\hline 1 & $R_{2112}^{4}$ & Basah & 1 \\
\hline 2 & $R_{2113}^{4}$ & Basah & 1 \\
\hline 3 & $R_{2114}^{4}$ & Basah & 1 \\
\hline 4 & $R_{2122}^{4}$ & Basah & 1 \\
\hline 5 & $R_{2123}^{4}$ & Basah & 1 \\
\hline 6 & $R_{2124}^{4}$ & Lembab & 0.808615 \\
\hline 7 & $R_{2132}^{4}$ & Basah & 1 \\
\hline 8 & $R_{2133}^{4}$ & Basah & 1 \\
\hline 9 & $R_{2134}^{4}$ & Lembab & 1 \\
\hline 10 & $R_{2142}^{4}$ & Basah & 1 \\
\hline 11 & $R_{2143}^{4}$ & Basah & 1 \\
\hline 12 & $R_{2212}^{4}$ & Basah & 1 \\
\hline 13 & $R_{2213}^{4}$ & Basah & 1 \\
\hline 14 & $R_{2114}^{4}$ & Basah & 1 \\
\hline 15 & $R_{2222}^{4}$ & Basah & 1 \\
\hline 16 & $R_{2223}^{4}$ & Basah & 1 \\
\hline 17 & $R_{2224}^{4}$ & Basah & 0.817073 \\
\hline 18 & $R_{2232}^{4}$ & Basah & 1 \\
\hline 19 & $R_{2233}^{4}$ & Basah & 1 \\
\hline 20 & $R_{2234}^{4}$ & Lembab & 1 \\
\hline 21 & $R_{2242}^{4}$ & Basah & 1 \\
\hline 22 & $R_{2243}^{4}$ & Basah & 1 \\
\hline 23 & $R_{3112}^{4}$ & Basah & 1 \\
\hline 24 & $R_{3113}^{4}$ & Basah & 1 \\
\hline 25 & $R_{3114}^{4}$ & Basah & 1 \\
\hline 26 & $R_{3122}^{4}$ & Basah & 1 \\
\hline 27 & $R_{3123}^{4}$ & Basah & 1 \\
\hline 28 & $R_{3124}^{4}$ & Lembab & 0.938905 \\
\hline 29 & $R_{3132}^{4}$ & Kering & 0.3314 \\
\hline 30 & $R_{3133}^{4}$ & Kering & 0.3314 \\
\hline 31 & $R_{3134}^{4}$ & Lembab & 1 \\
\hline 32 & $R_{3142}^{4}$ & Basah & 0.786671 \\
\hline 33 & $R_{3143}^{4}$ & Basah & 0.786671 \\
\hline 34 & $R_{3144}^{4}$ & Lembab & 1 \\
\hline 35 & $R_{3212}^{4}$ & Basah & 1 \\
\hline 36 & $R_{3213}^{4}$ & Basah & 1 \\
\hline 37 & $R_{3214}^{4}$ & Basah & 1 \\
\hline 38 & $R_{3222}^{4}$ & Basah & 1 \\
\hline 39 & $R_{3223}^{4}$ & Basah & 1 \\
\hline 40 & $R_{3224}^{4}$ & Basah & 0.514614 \\
\hline 41 & $R_{3232}^{4}$ & Basah & 1 \\
\hline 42 & $R_{3233}^{4}$ & Basah & 1 \\
\hline
\end{tabular}




\begin{tabular}{cccc}
\hline No. & $R_{i j k l}^{K}$ & Konklusi & $C F_{i j k l}^{K}$ \\
\hline 43 & $R_{3242}^{4}$ & Basah & 1 \\
44 & $R_{3243}^{4}$ & Basah & 1 \\
45 & $R_{4124}^{4}$ & Kering & 0.376341 \\
46 & $R_{4132}^{4}$ & Kering & 1 \\
47 & $R_{4133}^{4}$ & Kering & 1 \\
48 & $R_{4134}^{4}$ & Lembab & 0.819003 \\
49 & $R_{4142}^{4}$ & Kering & 1 \\
50 & $R_{4143}^{4}$ & Kering & 1 \\
51 & $R_{4144}^{4}$ & Lembab & 1 \\
52 & $R_{4224}^{4}$ & Lembab & 1 \\
53 & $R_{4234}^{4}$ & Lembab & 1 \\
\hline
\end{tabular}

g. Grid Partition Teradaptasi

Aturan yang dapat dibangkitkan dengan rekam data seperti pada table 5.11 untuk fase 1 adalah $\mathrm{SR}=\left\{R_{1111}^{2}, R_{1112}^{2}, R_{1121}^{2}, R_{1122}^{2}, R_{1211}^{2}\right.$, $R_{1212}^{2}, R_{1221}^{2}, R_{1222}^{2}, R_{2111}^{2}, R_{2112}^{2}, R_{2121}^{2}, R_{2122}^{2}$, $\left.R_{2211}^{2}, R_{2212}^{2}, R_{2221}^{2}, R_{2222}^{2}\right\}$.

Berdasarkan table 11, $R_{1122}^{2}$ dipilih karena memiliki bobot aturan yang terendah. Nilai K dan $\mathrm{K}$ pada fase 1 diinisialisasi dari $R_{1122}^{2}$, kemudian $\mathrm{K}=2 \mathrm{~K}$ sehingga nilai $\mathrm{K}=4$. Pada fase kedua ini, aturan yang berpotensi untuk dibangkitkan dari $R_{1122}^{2}$ dapat dijelaskan pada gambar 3 dan gambar 4 .

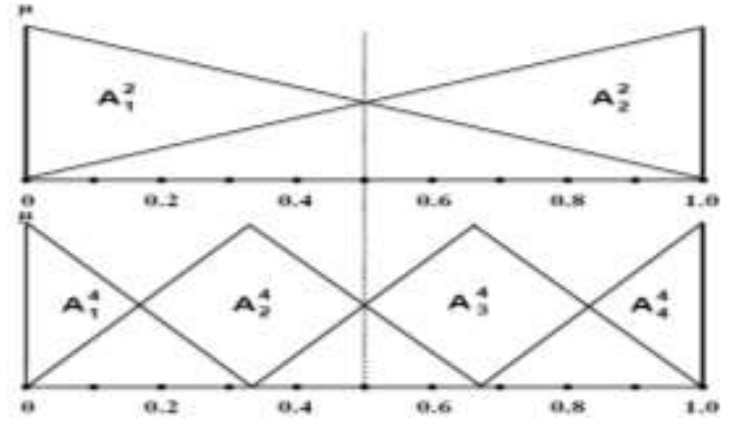

Gambar 3. Pelebelan $A_{i}^{K}$ pada $\mathrm{K}=2$ dan $\mathrm{K}=$ 2K Pada Satu Atribut
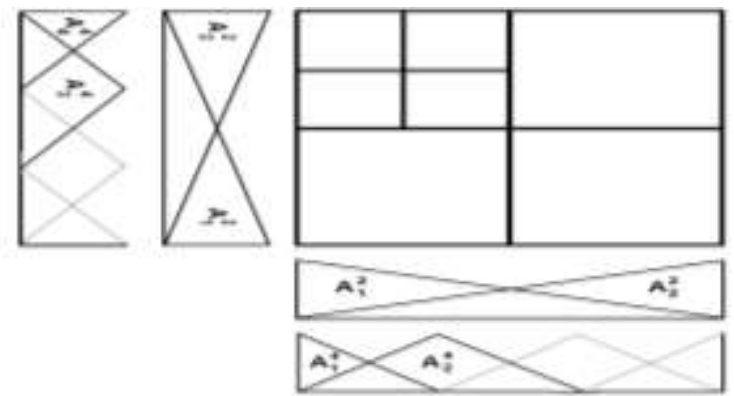

Gambar 4. Pelebelan $R_{i j}^{K}$ pada $\mathrm{K}=2$ dan $\mathrm{K}=$ 2K Pada Dua Atribut

Sesuai gambar 3 , label $A_{i}^{K}$ pada $\mathrm{K}=2$ adalah $A_{2}^{2}$, setelah $\mathrm{K}=2 \mathrm{~K}$, akan terbentuk $A_{4}^{3}$ dan $A_{4}^{4}$. Dengan menggunakan prinsip yang sama seperti pada gambar 4, aturan yang berpotensi untuk dibangkitkan dari $R_{1122}^{2}$ pada $\mathrm{K} \leftarrow 2 \mathrm{~K}$ adalah seperti pada tabel 14 .

Tabel 14. Pembangkitan Aturan Fuzzy dari $R_{1122}^{2}$ Pada KŁ2K

\begin{tabular}{ccccc}
\hline No. & $R_{i j k l}^{K}$ & BMax & Konklusi & $C F_{i j k l}^{K}$ \\
\hline 1 & $R_{2133}^{4}$ & 0.106854 & Basah & 1 \\
2 & $R_{2134}^{4}$ & 0.014247 & Lembab & 1 \\
3 & $R_{2143}^{4}$ & 0.106854 & Basah & 1 \\
4 & $R_{2233}^{4}$ & 0.010685 & Basah & 1 \\
5 & $R_{2234}^{4}$ & 0.000445 & Lembab & 1 \\
6 & $R_{2243}^{4}$ & 0.010685 & Basah & 1 \\
\hline
\end{tabular}

Berdasarkan langkah-langkah tersebut, maka aturan yang dibangkitkan adalah $\mathrm{S}_{\mathrm{R}}=\left\{R_{1111}^{2}\right.$, $R_{1112}^{2}, R_{1121}^{2}, R_{1122}^{2}, R_{1211}^{2}, R_{1212}^{2}, R_{1221}^{2}, R_{1222}^{2}$, $R_{2111}^{2}, R_{2112}^{2}, R_{2121}^{2}, R_{2122}^{2}, R_{2211}^{2}, R_{2212}^{2}, R_{2221}^{2}$, $\left.R_{2222}^{2}, R_{2133}^{4}, R_{2134}^{4}, R_{2143}^{4}, R_{2233}^{4}, R_{2234}^{4}, R_{2243}^{4}\right\} . \mathrm{S}_{\mathrm{R}}$ merupakan himpunan aturan yang dapat dibangkitkan yaitu sejumlah 22 aturan.

\subsection{Proses Klasifikasi}

Proses klasifikasi dilakukan untuk mengetahui keakuratan aturan yang telah dibangkitkan. Simulasi hasil perhitungan untuk rekam data no 55 pada kelas kering, lembab dan basah dapat dilihat pada table 15 , table 16 dan table 17 berikut:

Tabel 15. Nilai $\alpha_{\text {kering }}$ Berdasarkan Aturan Yang Dibangkitkan

\begin{tabular}{ccccccc}
\hline$R_{i j k l}^{K}$ & $\begin{array}{c}\mathrm{T} \text { is } \\
A_{i}^{K}\end{array}$ & $\begin{array}{c}\mathrm{CH} \\
\text { is } A_{j}^{K}\end{array}$ & $\begin{array}{c}\text { LPM } \\
\text { is } A_{k}^{K}\end{array}$ & $\begin{array}{c}\text { KA } \\
\text { is } A_{l}^{K}\end{array}$ & $C F_{i j k l}^{K}$ & $\alpha$ \\
\hline$R_{2111}^{2}$ & 0.67 & 1 & 0.3 & 0.5 & 0.5124 & 0.051496 \\
$R_{2112}^{2}$ & 0.67 & 1 & 0.3 & 0.5 & 0.3155 & 0.031708 \\
$R_{2121}^{2}$ & 0.67 & 1 & 0.7 & 0.5 & 0.5581 & $\mathbf{0 . 1 3 0 8 7 4}$ \\
\hline \multicolumn{7}{c}{$\alpha_{\max }$} \\
\hline
\end{tabular}

Tabel 16. Nilai $\alpha_{\text {Lembab }}$ Berdasarkan Aturan Yang Dibangkitkan

\begin{tabular}{ccccccc}
\hline$R_{i j k l}^{K}$ & $\begin{array}{c}\mathrm{T} \text { is } \\
A_{i}^{K}\end{array}$ & $\begin{array}{c}\mathrm{CH} \\
\text { is } A_{j}^{K}\end{array}$ & $\begin{array}{c}\mathrm{LPM} \\
\text { is } A_{k}^{K}\end{array}$ & $\begin{array}{c}\mathrm{KA} \\
\text { is } A_{l}^{K}\end{array}$ & $C F_{i j k l}^{K}$ & $\alpha$ \\
\hline$R_{1122}^{2}$ & 0.33 & 1 & 0.7 & 0.5 & 0.2091 & 0.024153 \\
$R_{2122}^{2}$ & 0.67 & 1 & 0.7 & 0.5 & 0.3032 & $\mathbf{0 . 0 7 1 0 9 7}$ \\
$R_{2134}^{4}$ & 0.06 & 0.97 & 0.24 & 1 & 1 & 0.014247 \\
$R_{2234}^{4}$ & 0.06 & 0.03 & 0.24 & 1 & 1 & 0.000445 \\
\hline \multicolumn{7}{c}{$\alpha_{\max }$} \\
\hline
\end{tabular}

Tabel 17. Nilai $\alpha_{\text {Basah }}$ Berdasarkan Aturan Yang Dibangkitkan

\begin{tabular}{|c|c|c|c|c|c|c|}
\hline$R_{i j k l}^{K}$ & $\begin{array}{l}\mathrm{T} \text { is } \\
A_{i}^{K}\end{array}$ & $\begin{array}{r}\mathrm{CH} \\
\text { is } A_{j}^{K} \\
\end{array}$ & $\begin{array}{l}\text { LPM } \\
\text { is } A_{k}^{K}\end{array}$ & $\begin{array}{l}\text { KA } \\
\text { is } A_{l}^{K}\end{array}$ & $C F_{i j k l}^{K}$ & $\alpha$ \\
\hline$R_{1111}^{2}$ & 0.33 & 1 & 0.3 & 0.5 & 0.3748 & $\begin{array}{c}0.0185 \\
53\end{array}$ \\
\hline$R_{1112}^{2}$ & 0.33 & 1 & 0.3 & 0.5 & 0.3166 & $\begin{array}{c}0.0156 \\
72\end{array}$ \\
\hline
\end{tabular}




\begin{tabular}{ccccccc}
\hline$R_{i j k l}^{K}$ & $\begin{array}{c}\mathrm{T} \text { is } \\
A_{i}^{K}\end{array}$ & $\begin{array}{c}\mathrm{CH} \\
\text { is } A_{j}^{K}\end{array}$ & $\begin{array}{c}\mathrm{LPM} \\
\text { is } A_{k}^{K}\end{array}$ & $\begin{array}{c}\mathrm{KA} \\
\text { is } A_{l}^{K}\end{array}$ & $C F_{i j k l}^{K}$ & $\alpha$ \\
\hline$R_{1121}^{2}$ & 0.33 & 1 & 0.7 & 0.5 & 0.3068 & $\mathbf{0 . 0 3 5 4}$ \\
$R_{1211}^{2}$ & 0.33 & 0 & 0.3 & 0.5 & & 0 \\
$R_{1212}^{2}$ & 0.33 & 0 & 0.3 & 0.5 & 0.9600 & 0 \\
$R_{1221}^{2}$ & 0.33 & 0 & 0.7 & 0.5 & 1 & 0 \\
$R_{1222}^{2}$ & 0.33 & 0 & 0.7 & 0.5 & 0.6070 & 0 \\
$R_{2211}^{2}$ & 0.67 & 0 & 0.3 & 0.5 & 1 & 0 \\
$R_{2212}^{2}$ & 0.67 & 0 & 0.3 & 0.5 & 0.9528 & 0 \\
$R_{2221}^{2}$ & 0.67 & 0 & 0.7 & 0.5 & 1 & 0 \\
$R_{2222}^{2}$ & 0.67 & 0 & 0.7 & 0.5 & 0.5295 & 0 \\
$R_{2133}^{4}$ & 0.06 & 0.97 & 0 & 0 & 1 & 0 \\
$R_{2143}^{4}$ & 0.06 & 0.03 & 0.24 & 0 & 1 & 0 \\
$R_{2233}^{4}$ & 0.06 & 0.03 & 0 & 0 & 1 & 0 \\
$R_{2243}^{4}$ & 0.33 & 1 & 0.3 & 0.5 & 0.3748 & 0.0185 \\
\hline \multicolumn{7}{c}{$\alpha_{\max }$} \\
\hline
\end{tabular}

\subsection{Hasil Klasifikasi}

Berdasarkan proses klasifikasi yg telah dilakukan, diperoleh nilai $\alpha$ yang terbesar ( $\alpha$ max) pada setiap rekam data. Pada nomor rekam data 55 nilai $\alpha_{\max }$ terletak pada kelas kering. Hasil klasifikasi menunjukkan benar yang berarti aturan yang dibangkitkan dapat mengklasifikasi data rekam nomor 55. Dengan cara yang sama, hasil klasifikasi yang dilakukan pada data dengan rekam data nomor 55 , nomor 91 , nomor 37 , nomor 46 , nomor 86 , dan nomor 98, dengan menggunakan aturan yang dibangkitkan dapat dilihat pada tabel 18 .

Tabel 18. Hasil Klasifikasi

\begin{tabular}{cccc}
\hline $\begin{array}{c}\text { No. } \\
\text { Rekam } \\
\text { Data }\end{array}$ & $\alpha_{\max }$ & Kelas & $\begin{array}{c}\text { Hasil } \\
\text { Klasifikasi }\end{array}$ \\
\hline 55 & 0.1309 & Kering & Benar \\
91 & 0.2082 & Kering & Benar \\
37 & 0.1179 & Kering & Salah \\
46 & 0.1837 & Lembab & Benar \\
86 & 0.1069 & Basah & Benar \\
98 & 0.1469 & Kering & Salah \\
\hline
\end{tabular}

Berdasarkan tabel 18, tingkat keakuratan rules yang dibangkitkan adalah sebagai berikut:

$$
\begin{aligned}
& \text { akurasi }(\%)=\frac{\sum \text { klasifikasi yang benar }}{\sum \text { klasifikasi keseluruhan }} \times 100 \\
& \text { akurasi }(\%)=\frac{4}{6} \times 100 \% \\
& \text { akurasi }(\%)=66,67 \%
\end{aligned}
$$

sedangkan tingkat error (kesalahan) dari rules yang telah dibangkitkan sebagai berikut:

$$
\begin{aligned}
& \text { error }(\%)=\frac{\sum \text { klasifikasi yang salah }}{\sum \text { klasifikasi keseluruhan }} \times 100 \% \\
& \text { error }(\%)=\frac{2}{6} \times 100 \% \\
& \text { error }(\%)=33,33 \%
\end{aligned}
$$

Jumlah unclass (data yang tidak dapat diklasifikasi) sebagai berikut:

unclass $=$ Eklasifikasi keseluruhan - $\quad(\Sigma$ klasifikasi benar $+\Sigma$ klasifikasi salah)

unclass $=6-(4+2)$

unclass $=0$

\section{Kesimpulan}

Metode fuzzy grid partition dapat mengklasifikasikan data tidak lengkap. Data tidak lengkap terlebih dahulu di proses dengan pendekatan mengganti nilai atribut yang hilang dengan rata-rata atau median dari atribut untuk semua objek yang memiliki kelas keputusan yang sama. Aturan fuzzy yang dibangkitkan dengan metode grid partition teradaptasi menghasilkan 22 himpunan aturan. Dari pengujian enam rekam data, akurasi aturan yang dibangkitkan menghasilkan $66,67 \%$ hasil klasifikasi dinyatakan benar, $33,33 \%$ hasil klasifikasi dinyatakan error dan nilai unclass adalah 0 yang berarti semua data dapat diklasifikasikan.

\section{Referensi}

Agarwal, S. (2014). Data mining: Data mining concepts and techniques. In Proceedings 2013 International Conference on Machine Intelligence Research and Advancement, ICMIRA 2013. https://doi.org/10.1109/ ICMIRA.2013.45

Borgi, A. (2018). Attributes regrouping in Fuzzy Rule Based Classification Systems: an intra-classes approach. 2018 IEEE/ACS 15th International Conference on Computer Systems and Applications (AICCSA), 1-7.

Chen, T., Shen, Q., Su, P., \& Shang, C. (2016). Fuzzy rule weight modification with particle swarm optimisation. Soft Computing, 20(8), 2923-2937. https://doi.org/10.1007/ s00500-015-1922-z

Dahal, K., Almejalli, K., Hossain, M. A., \& Chen, W. (2015). GA-based learning for rule identification in fuzzy neural networks. Applied Soft Computing Journal, 35, 605617.

https://doi.org/10.1016/j.asoc.2015.06.046

Elkano, M., Galar, M., Sanz, J., \& Bustince, H. (2016). Fuzzy Rule-Based Classification Systems for multi-class problems using binary decomposition strategies: On the influence of $n$-dimensional overlap functions in the Fuzzy Reasoning Method. Information Sciences, 332, 94-114. https://doi.org/10.1016/j.ins.2015.11.006

Field, D., \& Zhao, L. (2018). Feature Selection Method based on GridPartition + IEEE. 52- 
57.

Hartono. (2016). Optimization of Tsukamoto Fuzzy Inference System using Fuzzy Grid Partition. IJCSN International Journal of Computer Science and Network, 5(5), 2277-5420. Retrieved from www.IJCSN.org

Liu, X., Feng, X., \& Pedrycz, W. (2013). Extraction of fuzzy rules from fuzzy decision trees: An axiomatic fuzzy sets (AFS) approach. Data and Knowledge Engineering, 84, 1-25. https://doi.org/ 10.1016/j.datak.2012.12.001

Mao, L., Chen, Q., \& Sun, J. (2020). Construction and Optimization of Fuzzy Rule-Based Classifier with a Swarm Intelligent Algorithm. 2020. https://doi.org/10.1155/2020/9319364

Marbun, M., Ramdhan, W., Priyanto, D., \& Zarlis, M. (2019). Philosophy of Fuzzy Logic as Fundamental of Decision Making Based On Rule Philosophy of Fuzzy Logic as Fundamental of Decision Making Based On Rule. https://doi.org/10.1088/17426596/1230/1/012021

Sadiq, A. T., Duaimi, M. G., \& Shaker, S. A. (2012). Data missing solution using rough set theory and swarm intelligence. Proceedings - 2012 International Conference on Advanced Computer Science Applications and Technologies, ACSAT 2012, 3, 173-180. https://doi.org/ 10.1109/ACSAT.2012.29
Sadouki, L., \& Haddad, B. (2016). Adaptive Neuro-Fuzzy Inference System for Echoes Classification in Radar Images. 4(Visigrapp), 159-166. https://doi.org/ 10.5220/0005717401590166

Sinambela, M. S., Rosely, E., \& Mayadewi, R. P. (2016). THE DECISION SUPPORT SYSTEM FOR SUBJECT SPECIALIZATION STUDENTS IN. 2(3), 858-866.

Sitompul, opim salim; Nababan, Erna Budhiarti; Alim, Z. (2017). Adaptive Dsitibuted GridPartition in Generating Fuzzy Rules. 119124.

Takahashi, Y., Nojima, Y., \& Ishibuchi, H. (2015). Rotation effects of objective functions in parallel distributed multiobjective fuzzy genetics-based machine learning. 2015 10th Asian Control Conference: Emerging Control Techniques for a Sustainable World, ASCC 2015, (C), 1-6. https://doi .org/10.1109/ASCC.2015.7244890 